\title{
HUBUNGAN ANTARA KEBIASAAN CARA MEMASAK SAYURAN DAN KADAR CHOLINESTERASE TERHADAP STATUS HORMON THYROID WANITA USIA SUBUR DI DAERAH GONDOK ENDEMIK
}

\author{
Sukati Saidin ${ }^{1}$, Nurdin$^{2}$, Hardinsyah ${ }^{3}$, Ikeu Tanziha ${ }^{3}$ \\ ${ }^{1}$ Pusat Penelitian dan Pengembangan Gizi dan Makanan, Bogor \\ ${ }^{2}$ Mahasiswa S3 Fakultas Ekologi Manusia, IPB \\ ${ }^{3}$ Institut Pertanian Bogor
}

\section{ABSTRACT \\ THE ASSOCIATION BETWEEN FREE THYROXINE AND VEGETABLES COOKING AND SERUM CHOLINESTERASE OF CHILD BEARING AGE WOMEN IN ENDEMIC GOITRE AREA}

Pesticides, a goitrogenic pollutant, strongly bind iodine to make a complex substance which iodine can not optimally be utilized and leads to impair thyroxine hormone production. Farmers in Pakis sub district of Magelang district often put pesticides of organophosphate and carbamate groups to increase vegetables yield. The retained pesticides in the foods can be minimized by cooking. To determine the association between free thyroxine sera and vegetable cooking and cholinesterase sera. A cross-sectional study design was applied to 205 of child bearing age women (CBAW) of 17 - 45 years of age in Pakis sub district of Magelang District, Central Java. Vegetable in which pesticide may persist were cooked in two ways, namely were boiled and tumis (stir fried). Blood spicement were drawn for $\mathrm{fT} 4$ and cholinesterase axamination. It was indicated that serum FT4 of $68,3 \%$ of CBAW were normal, while $31,7 \%$ of them were low and $5.1 \%$ of CBAW with low serum CHE. There was a significant association between the way of cooking, status of serum CHE and contraceptive use of family planning with to status of serum FT4. The child bearing age women that consume vegetables cooked by "tumis" (cooking stir fried) having higher risk of low serum free thyroxin status, 2,5 times than that of by boiling. CBAW with low cholinesterase enzyme (CHE) having lower risk of low serum free thyroxin hormone status (FT4), 10 times than that of with normal CHE. CBAW with hormonal contraception having higher risk of low serum FT4, 0,50 times than that usage non hormonal contraception. In order to minimize pesticide residues retained in vegetables, it should be cooked by boiling

Key words: iodine status, pesticide, cholinesterase, cooking stir fried, child bearing age women, thyroxine status, endemic goiter

\section{PENDAHULUAN}

estisida termasuk zat polutan yang goitrogenik, dapat membentuk ikatan kompleks yang sangat kuat dengan iodium di dalam tubuh, sehingga iodium tersebut tidak dapat dimanfaatkan secara optimal. Akibatnya proses pembentukan hormon tiroid terganggu'.

Hasil evaluasi proyek penanggulangan GAKI (Gangguan Akibat Kekurangan lodium) tingkat nasional tahun 2003, menunjukkan angka TGR (Total Goitre Rate) di Kabupaten Magelang sebesar 19,9 persen dengan median kadar iodium dalam urine (UIE) sebesar $229 \mu \mathrm{g} / \mathrm{L}^{2}$. Hasil evaluasi ini menunjukkan bahwa konsumsi iodium harian cukup, tetapi angka TGR tinggi. Ini merupakan indikasi bahwa asupan iodium tidak dapat dimanfaatkan oleh tubuh , karena ada zat penghambat yang diduga berasal dari penggunaan pestisida di kabupaten Magelang.

Di kecamatan Pakis Kabupaten Magelang sebagian besar penduduknya adalah petani sayuran.. Untuk memperoleh hasil panen sayuran yang optimal petani melakukan pengendalian hama dengan penyemprotan pestisida. Penggunaan pestisida yang kurang tepat dapat 
menyebabkan keracunan. Menurut harian Republika telah terjadi kematian misterius yang menimpa sembilan orang warga desa Kanigoro, Kecamatan Ngablak, Kabupaten Magelang. Laboratorium Dinas Kesehatan Kabupaten Magelang memastikan penyebab kematian tersebut adalah keracunan pestisida $^{3}$.

Zat-zat polutan seperti pestisida yang termakan dapat menghambat pengikatan iodium pada saat pembentukan mono dan diioditirosin atau sebagai prekusor hormone $\mathrm{T}_{3}$ (triiodotironin) dan $\mathrm{T}_{4}$ (tiroksin), sehingga pembentukan hormon $\mathrm{T}_{3}$ dan $\mathrm{T}_{4}$ terhambat' Untuk mencukupi kebutuhan $T_{3}$ dan $T_{4}$ dalam tubuh, maka kelenjar tiroid akan bekerja keras, sehingga sel-sel kelenjar akan membesar, dan secara visual leher akan membesar ${ }^{4}$.

Residu pestisida yang tertinggal pada bahan makanan dapat dikurangi dengan cara pemasakan. Alsuhendra ${ }^{5}$, dalam penelitiannya menunjukkan bahwa perebusan dapat mengurangi pestisida dalam bahan makanan. Oleh karena itu tulisan ini akan menjajikan hasil analisis lanjutan data yang sudah ada untuk mempelajari apakah ada hubungan karakteristik responden dan cara pemasakan sayuran di rumah tangga dengan status enzim kolinesterase dikaitkan dengan status hormon tiroid (kadar T4 bebas).

\section{METODE}

\section{Desain, Waktu dan Tempat}

Desain penelitian ini adalah potonglintang (cross-sectional). Data yang digunakan dalan tulisan ini adalah bagian dari data laporan Saidin S., dkk (2005) yang berjudul: "Hubungan Status Pestisida dengan Status lodium dalam Daerah pada Wanita Usia Subur di Daerah Gondok Endemik Kabupaten Magelang "6.

\section{Partisipan}

Partispan penelitian adalah WUS dengan umur 17-45 tahun yang tinggal di Kecamatan Pakis minimal tiga tahun. Sampel makanan adalah bahan makanan (sayuran) yang tercemar pestisida yang diambil dari rumah tangga dan dari pasar.

Jumlah partisipan yang diperlukan untuk penelitian ini, dihitung dengan perkiraan kelompok WUS yang terpapar pestisida tinggi berisiko mempunyai kadar $T_{4}$ rendah (OR) sebesar 1,5 x dibandingkan dengan kelompok WUS yang terpapar pestisida rendah. Dari Tabel $9 \mathrm{~K}$ (halaman 159) pada buku Lameshow (1993) dengan P2 = 45\%, a $=90 \%$ dan tingkat kesalahan yang dapat ditolerir $(d)=25 \%$, maka diperlukan sampel minimal sebesar 265 orang (Lameshow et al., 1993) ${ }^{7}$.

Untuk keperluan tulisan ini, digunakan kriteria pemilihan sampel sebagai berikut : WUS berumur 17-45 thn, tidak hamil dan tidak menyusui, ada data cara memasak (rebus dan tumis). Kriteria eksklusinya adalah pengguna obat antitiroid.

\section{Cara Pengumpulan Data}

Peubah dependen penelitian ini adalah status iodium dengan mengukur kadar hormon $\mathrm{T}_{4}$ bebas (FT4). Sedangkan peubah independen adalah: penggunaan kontrasepsi, cara memasak sayuran (sudah dibersihkan, dan dipotong-potong), sumber air minum, dan kadar enzim cholinesterase (CHE) dalam serum darah.

Data identititas yang dikumpulkan adalah nama, umur, tinggi, berat badan, alamat, pendidikan, pekerjaan, cara pemasakan sayuran dan penggunaan kontrasepsi dikumpulkan dengan cara wawancara. Sedangkan data biokimia yaitu: pengambilan darah dilakukan satu kali oleh perawat/petugas laboratorium yang berpengalaman. Darah diambil sebanyak 5 $\mathrm{ml}$ untuk pemeriksaan kadar $\mathrm{FT}_{4}$ dan $\mathrm{CHE}$. Specimen darah dari lapangan disimpan dalam cool box. Setelah sampai di laboratorium, darah disentrifus untuk diambil serumnya dan disimpan dalam freezer ($\left.20^{\circ} \mathrm{C}\right)$.

Kadar hormon $\mathrm{T}_{4}$ bebas (FT4) dianalisis menggunakan kit produksi Human dengan metode ELISA (Enzym Link Immunosorbant Assay). Kadar iodium dalam urin dianalisis dengan metode Wet Digestion, seperti yang dianjurkan oleh ICCIDD 
$d k k$.

(WHO/UNICEF/ICCIDD, 2001(8). Kadar enzim CHE dalam serum sebagai indikator keracunan pestisida dianalisis dengan spektrofotometer.

Analisis FT4 dilakukan di laboratorium GAKI Borobodur Magelang. Analisis CHE dilakukan di laboratorium Puslitbang Gizi dan Makanan Bogor. Analisis pestisida dalam sayuran dan air dilakukan di Laboratorium Terpadu UGM menggunakan metode gas kromatografi. CHE dalam serum dihidrolisis dengan butyrythiocholine menjadi butyryc acid dan thiocholine. Thiocholine akan menurunkan warna kuning pada potasium hexacyanoferrate (III) menjadi hexacyanoferrate (II). Penurunan warna diukur menggunakan spektrofotometer pada panjang gelombang $405 \mathrm{~nm}$.

Analisis kadar FT4 dilakukan dalam 3 tahap, masing-masing: (a) tahap inkubasi awal adalah pemecahan $T_{4}$ dari protein

$$
Y=\log \frac{f}{1-f}=\beta_{0}+\beta_{1} X_{1}+\beta_{2} X_{2}+\beta_{3} X_{3}+\beta_{4} X_{4}
$$

\section{HASIL}

Dari 271 sampel pada data awal, setelah dilakukan penapisan diperoleh sebanyak 205 sampel yang memenuhi kriteria. Pengolahan data karakteristik responden disajikan pada Tabel 1 .

Pada Tabel 1, terlihat bahwa pendidikan responden sebagian besar adalah tidak pernah sekolah sampai tidak lulus SLTP. Status gizi ditentukan berdasarkan indeks masa tubuh (IMT), dan sebagian besar termasuk normal dan yang termasuk kurus sebesar 4,9,2 persen. Sebagian besar WUS tidak menggunakan kontrasepsi yang mengandung hormonal yaitu: IUD, kondom dan kalender; sedangkan sebagian lainnya menggunakan alat kontrasepsi hormonal seperti pil KB, susuk dan suntik. Partisipan mempunyai kebiasaan memasak sayuran dengan cara merebus dan tumis masingmasing sebesar 23,9 dan 76,1 persen. $\mathrm{f}=$ adalah peluang menderita kekurangan $\mathrm{FT} 4$ )

pengikat dengan buffer konjugasi di dalam tabung antibody-coated tubes diinkubasi selama 60 menit, (b) tahap pencucian: sisasisa buffer konjugasi dibuang dan dicuci dengan substrat yaitu campuran buffer fosfat dan Na-perborat selama 30 menit, dan (c) tahap pengukuran. Larutan dibaca dengan alat EIA Reader Model 2550 pada panjang gelombang $405 \mathrm{~nm}$.

\section{Pengolahan dan Analisis Data}

Untuk menganalisis pengaruh dari beberapa variabel independen digunakan model regresi logistik ${ }^{9}$. Analisis regresi logistik merupakan salah satu pendekatan model matematis yang digunakan untuk menganalisis hubungan satu atau beberapa variabel independen dengan sebuah variabel independen kategorik yang bersifat dikotomi/ binary.

Adapun model regresi logistiknya sebagai berikut:

Pada Tabel 1 diperlihatkan pula bahwa responden yang menggunakan sumber air minum sebagai petunjuk sanitasi lingkungan, sebanyak 93,2 persen. Air yang digunakan berasal dari sumur atau air bersih dari puncak gunung yang disalurkan ke rumahruamah dengan pipa paralon.

Batas normal kadar $\mathrm{FT}_{4}$ dalam darah adalah $0,8-2,0 \mathrm{ug} / \mathrm{dL}$. Bila kadar $\mathrm{FT}_{4}$ kurang dari $0,8 \mathrm{ug} / \mathrm{dL}$ dikatakan rendah atau kurang (hipotiroksinemia). Kadar $\mathrm{FT}_{4}$ dapat sebagian partisipan berada dalam kisaran normal.

Status enzim kolinesterase seperti terlihat pada Tabel 1, menunjukkan bahwa persentase partisipan dengan kadar CHE rendah sebesar 5,1 persen. Kisaran normal untuk kadar enzim kolinesterase (CHE) menurut Depkes adalah $3600-10.000$ I.U dan bila kurang dari 3600 I.U dikatakan rendah ${ }^{11}$. 
Tabel 1

Karakteristik responden

\begin{tabular}{|c|c|c|}
\hline Variabel Independen & $\mathrm{n}$ & $\%$ \\
\hline \multicolumn{3}{|l|}{ Status $\mathrm{fT}_{4}$} \\
\hline Normal, $\mathrm{fT}_{4} \geq 0,80 \mathrm{ng} / \mathrm{L}$ & 140 & 68,3 \\
\hline $\begin{array}{l}\text { Rendah, } \mathrm{fT}_{4}<0,80 \mathrm{ng} / \mathrm{L} \\
\text { IMT10. }\end{array}$ & & 31,7 \\
\hline$<18,5$ : kurus & 10 & 4,9 \\
\hline $18,5-25,0:$ normal & 165 & 80,5 \\
\hline$>25,0$ : gemuk & 30 & 14,6 \\
\hline \multicolumn{3}{|l|}{ Pendidikan responden: } \\
\hline Akademi & 1 & 0,5 \\
\hline Tamat SMP dan tamat SMA & 30 & 14,6 \\
\hline Tidak sekolah,tidak tamat SD,tamat SD & 174 & \\
\hline \multicolumn{3}{|l|}{ Penggunaan kontrasepsi: } \\
\hline Nonhormonal & 145 & 70,7 \\
\hline Hormonal & 60 & 29,3 \\
\hline \multicolumn{3}{|l|}{ Kadar enzim cholinesterase (CHE): } \\
\hline$\geq 3600$ (normal) & 194 & 94,9 \\
\hline$<3600$ (rendah) & 11 & 5,1 \\
\hline \multicolumn{3}{|l|}{ Sumber air minum: } \\
\hline Sehat & 191 & 93,2 \\
\hline Tidak sehat & 14 & 6,8 \\
\hline \multicolumn{3}{|l|}{ Cara memasak: } \\
\hline Rebus (0) & 49 & 23,9 \\
\hline Tumis dan lainnya (1) & 156 & 76,1 \\
\hline
\end{tabular}

Hubungan cara memasak dengan status kadar enzim kolinesterase (CHE)

Cara memasak sayuran dengan perebusan dapat mengurangi residu pestisida. Menurut Alsuhendra (1998), cara perebusan seperti sayur sup dan sayur asam dapat mengurang kadar residu pestisida yang tertinggal di sayuran.

Tabel 2

Status kadar enzyme kolinesterasi menurut cara memasak

\begin{tabular}{cccccc}
\hline & \multicolumn{4}{c}{ Kolinesterase } & \\
\cline { 2 - 5 } Cara memasak & \multicolumn{3}{c}{$\mathrm{N}(0)$} & \multicolumn{3}{c}{$\mathrm{R}(1)$} & \multirow{2}{*}{ Total } \\
\cline { 2 - 5 } & $\mathrm{n}$ & $\%$ & $\mathrm{n}$ & $\%$ & \\
\hline - Rebus (0) & 48 & 98,0 & 1 & 2,0 & 49 \\
- Tumis (1) & 147 & 94,2 & 9 & 5,8 & 156 \\
& 195 & & 10 & & 205 \\
\hline
\end{tabular}

$\mathrm{X} 2=1,117$ dan $p=0,221$

Pada Tabel 2, terlihat bahwa kelompok WUS dengan cara masak rebus yang mempunyai status kadar kolinesterase (CHE) rendah sebesar 2,0 persen lebih rendah dibandingkan dengan kelompok WUS yang memasak dengan cara tumis $(5,8 \%)$. Secara statistik tidak ada perbedaan yang bermakna $(p>0.05)$. Hal ini dapat 
dimengerti karena pengaruh pestisida terhadap kadar kolinesterase (CHE) dalam tubuh berifat "reversible" dan berlangsung sangat cepat ${ }^{12}$. Oleh karena itu variabel cara masak untuk selanjutnya dimasukkan sebagai variabel yang berhubungan dengan status kadar hormone tiroid (FT4).

\section{Hubungan antar variabel}

Untuk mengetahui adanya hubungan antara 2 variabel dilakukan uji bivariat. Hasil uji bivariat disajikan pada Tabel 3 .

Tabel 3

Hasil uji bivariat antara status hormon tiroid dengan variabel yang diduga berhubungan

\begin{tabular}{|c|c|c|c|}
\hline No & Variabel Independen & $95 \% \mathrm{Cl}(\mathrm{OR})$ & $p$ \\
\hline $\mathrm{X} 1$ & $\begin{array}{l}\text { Penggunaan kontrasepsi: } \\
\text { Nonhormonal (0) }\end{array}$ & & \\
\hline & Hormon (1) & $0,27-0,99(0,52)$ & 0,045 \\
\hline $\mathrm{X} 2$ & $\begin{array}{l}\text { Kadar enzym cholinesterase (CHE): } \\
\geq 3600 \text { (normal) (0) }\end{array}$ & & \\
\hline & $<3600$ (rendah) (1) & $1,87-41,24(8,79)$ & 0,006 \\
\hline X3 & $\begin{array}{l}\text { Sumber air minum: } \\
\text { Air sehat }(0) \\
\text { Tidak sehat }\end{array}$ & $0183-200(0605)$ & 0.347 \\
\hline X4 & $\begin{array}{l}\text { Cara masak: } \\
\text { Rebus (0) } \\
\text { Tumis (1) }\end{array}$ & $1,03-4,24(2,09)$ & 0,042 \\
\hline
\end{tabular}

Pada Tabel 3, tampak bahwa variabel yang mempunyai hubungan bermakna dengan status hormone T4 bebas (FT4) dengan $p<0,05$ adalah kadar enzim kolinesterase(CHE), cara masak dan jenis alat kontrasepsi atau alat KB yang digunakan.

\section{Faktor-faktor yang berpengaruh terhadap Status hormone Tiroid (FT4)}

Untuk menentukan faktor-faktor yang berpengaruh terhadap status hormon tiroksin bebas $\left(\mathrm{FT}_{4}\right)$ dalam darah digunakan analisis regresi logistik. Kadar $\mathrm{T}_{4}$ bebas (FT4) akan berkurang bila seseorang terpapar pestisida. Variabel dependen status hormon $\mathrm{FT}_{4}$ dibuat dikotomi yaitu normal (0) bila $\mathrm{T}_{4}$ bebas $(\mathrm{FT} 4) \geq 0,79 \mu \mathrm{g} / \mathrm{L}$ dan kurang (1) bila $\mathrm{T}_{4}$ bebas $(\mathrm{FT} 4)<0,79 \mu \mathrm{g} / \mathrm{L}$. Variabel independen yang mempunyai hubungan bermakna dengan status $\mathrm{T}_{4}$ bebas(FT4) adalah cara memasak sayuran, dan kadar
CHE dalam darah dan penggunaan alat kontrasepsi seperti tampak pada Tabel 4. Pada Tabel 4 juga tampak bahwa cara memasak sayuran dengan cara tumis menyebabkan WUS berisiko 2,5 kali mengalami status hormon $\mathrm{FT}_{4}$ rendah dibanding dengan WUS yang mengonsumsi sayuran dengan cara direbus.

Hal ini dapat dipahami karena cara pemasakan sayuran dengan cara ditumis menggunakan air yang relatif sedikit di bandingkan dengan cara rebus, sehingga konsentrasi pestisidanya relatif tinggi (dengan asumsi sumber dan jenis sayuran adalah sama). Cara rebus menyebabkan pestisida menjadi terlarut dan praktis konsentrasinya menurun dalam sayuran yang telah direbus. Alsuhendra (1998) melaporkan bahwa perebusan, pemasakan sop dan sayur asam dapat menurunkan kadar residu pestisida dalam bahan makanan. 
Tabel 4

Hasil analisis regresi logistik (multivariat) antara status $T_{4}$ bebas dengan variabel independen

\begin{tabular}{|c|c|c|c|}
\hline Peubah & OR & $95 \% \mathrm{Cl}(\mathrm{OR})$ & $p(O R)$ \\
\hline \multicolumn{4}{|c|}{ Kadar enzym cholinesterase (CHE): } \\
\hline $\begin{array}{ll}-\geq 3600 \text { (normal) } & (1) \\
-<3600 \text { (rendah) } & (0)\end{array}$ & $\begin{array}{c}1 \\
9,458\end{array}$ & $1,967-45,487$ & 0,005 \\
\hline \multicolumn{4}{|l|}{ Cara memasak: } \\
\hline - Rebus (banyak air) (0) & 1 & & \\
\hline - Tumis (sedikit air) (1) & 2,501 & $1,167-5,317$ & 0,017 \\
\hline \multicolumn{4}{|l|}{ Jenis kontrasepsi } \\
\hline - $\quad$ Non hormonal(0) & 1 & & \\
\hline - Hormonal(1) & 0,450 & $0.227-0,894$ & 0,023 \\
\hline Konstanta & $-2,513$ & & 0,000 \\
\hline
\end{tabular}

Untuk mengetahui pengaruh variabel memenuhi model hasilnya disajikan keseluruhan variabel yang berpengaruh pada Tabel 5 . terhadap status kadar hormon $\mathrm{T} 4$, bila

Tabel 5

Hasil Uji Multivariat variabel status CHE, Cara Masak dan Jenis Alat KB secara bersama-sama terhadap Status Hormon Tiroid( FT4)

\begin{tabular}{|c|c|c|c|c|c|c|c|c|}
\hline & \multirow{2}{*}{ B } & \multirow{2}{*}{ S.E } & \multirow{2}{*}{ Wald } & \multirow{2}{*}{ Df } & \multirow{2}{*}{ Sig. } & \multirow{2}{*}{$\operatorname{Exp}(B)$} & \multicolumn{2}{|c|}{$95.0 \%$ C.l.for $\operatorname{EXP}(\mathrm{B})$} \\
\hline & & & & & & & Lower & Upper \\
\hline \multicolumn{9}{|l|}{ Step1 } \\
\hline st_che (1) & 2.247 & .801 & 7.862 & 1 & .005 & 9.458 & 1.967 & 45.487 \\
\hline Cara_masak(1) & .917 & .385 & 5.674 & 1 & .017 & 2.501 & 1.176 & 5.317 \\
\hline Jenis Alat KB(1) & -.798 & .350 & 5.199 & 1 & .023 & .450 & .227 & .894 \\
\hline Constant & -1.064 & .346 & 9.444 & 1 & .002 & .345 & & \\
\hline
\end{tabular}

a.Variable(s) entered on step 1: st_che, cara_masak dan jenis alat KB

Pada Tabel 5 , terlihat bahwa nilai e $1,064+2,247$ (st CHE) + 0,916 (cara masak) 0,798 ( jenis alat KB), bila dimasukkan dalam model diperoleh nilai $\mathrm{OR}$ bersama sebesar 3,69. Dengan demikian dapat diambil kesimpulan bahwa resiko WUS di daerah gondok dengan kadar CHE rendah, memasak dengan cara tumis dan menggunakan alat KB hormonal untuk menderita hipotiroid sebesar 3,69 kali dibandingkan WUS dengan kadar CHE normal, masak sayur direbus dan menggunakan alat kontrasepsi non hormonal.

\section{BAHASAN}

Petani pada penelitian ini untuk membasmi serangga dalam usaha meningkatkan hasil atau produksi sayuran menggunakan pestisida jenis Organofaofat dan Carbamat. Departemen Kesehatan menggunakan kadar enzim kolinesterase (CHE) untuk memonitor keracunan pestisida 
Organofosfat dan Karbamat di tingkat petani Hasil monitoring DepKes thn 1997 tentang keracunan pestisida Organofosfat dan Karbamat pada petani penjamah pestisida di 27 propinsi Indonesia menunjukkan jumlah petani dengan aktivitas kolinesterase normal sebesar 61,8 persen, 1,3 persen keracunan berat, 9,98 persen keracunan sedang dan 26,89 persen keracunan ringan ${ }^{12}$.

Hasil penelitian ini menunjukkan bahwa proporsi WUS dengan kadar enzim kolinesterase (CHE) rendah sebesar 5,1 persen. Angka ini merupakan indikator bahwa WUS di daerah penelitian jelas terpapar pestisida jenis Organofosfat dan Karbamat. Kedua pestisida ini mempunyai efek memblokade penyaluran impuls syaraf dengan cara mengikat enzim kolinesterase(CHE) Menurut Lu, 1998 ${ }^{13}$ pestisida jenis Karbamat pengaruhnya terhadap kadar enzim CHE tidak berlangsung lama, karena prosesnya sangat cepat dan "reversible" Pada umumnya pestisida kelompok ini hanya bertahan dalam tubuh antara 1- 2 jam, kemudian dibuang. Sedangkan jenis Organofosfat berpotensi karsinogenik dan pengaruhnya lebih bersifat "irreversible". Hambatan pada enzim CHE akan menyebabkan terjadinya penumpukan asetilkolin, sehingga dapat menimbulkan efek muskarinik, nikotenik maupun menurunkan fungsi syaraf pusat dan dapat berakibat fatal ${ }^{14}$. Jadi walaupun persentase WUS dengan kadar enzim kolinesterase (CHE) rendah kecil hanya 5,1 persen, tetap harus diwaspadai, karena ada kemungkinan angka yang sebesarnya lebih besar dari 5,1 persen.

Alsuhendra ${ }^{4}$ melaporkan bahwa cara masak rebus dapat menurunkan kadar pestisida dalam sayuran yang terkontaminasi oleh pestisida, sehingga pestisida yang masuk dalam tubuh bisa berkurang. Salah satu cara untuk melihat besarnya pestisida yang masuk dalam tubuh adalah kadar enzim kolinesterase (CHE) dalam darah. Pada Tabel 2, terlihat bahwa WUS yang mempunyai kebiasaan memasak sayuran dengan cara rebus yang mempunyai kadar enzim kolinesterase rendah hanya sebesar 2,0 persen, lebih rendah dibandingkan dengan WUS yang memasak sayuran dengan cara tumis $(5,6 \%)$. Walaupun secara statistik tidak berbeda, tetapi data ini dapat diterima karena menurut $\mathrm{Lu}^{12}$ pengaruh pestisida jenis karbamat terhadap kadar enzim kolinesterase tidak berlangsung lama, jadi pada saat pemeriksaan darah ada kemungkinan kadar kolinesrerase sudah normal kembali. Oleh karena itu variabel cara memasak dimasukkan kedalam variabel yang berpengaruh terhadap status kadar hormon T4 bebas(FT4). Hasil anailisis multivariat ( Tabel 4) terbukti cara memasak berpengaruh nyata terhadap status kadar hormon T4 bebas (FT4).

Pada Tabel 4 terlihat bahwa kelompok WUS dengan cara masak tumis lebih beresiko mempunyai status yodium rendah sebesar 2,5 X dibandingkan dengan WUS yang memasak dengan cara rebus. Jadi dapat disimpulkan bahwa cara masak rebus lebih baik dalam hal menurunkan kandungan pestisida dalam makanan dibanding cara masak tumis.

Hasil penelitian juga menunjukkan bahwa kadar enzim kolinesterase sebagai gambaran adanya cemaran pestisida yang masuk dalam tubuh berpengaruh nyata terhadap kejadian rendahnya status yodium pada WUS yang tinggal di daerah gondok endemik. WUS dengan kadar CHE rendah sebesar 10 kali untuk mengalami status yodium rendah. Angka ini lebih rendah dibandingkan hasil penelitian Saidin. $S^{6}$, karena karakteristik sampel agak berbeda. Penelitian ini hanya menganalisis kelompok WUS dengan cara masak rebus dan tumis $(n=205)$. Sedangkan penelitian Saidin.S menganalisis seluruh WUS yang tinggal di daerah gondok endemik termasuk WUS dengan besar sampel ( $n=271$ orang).

Pada Tabel 4, terlihat juga bahwa penggunaan alat kontrasepsi hormonal juga merupakan variabel berpengaruh terhadap status kadar T4 bebas(FT4) rendah. WUS yang menggunakan alat KB hormonal beresiko 0,5 kali untuk mengalami status yodium rendah. Dengan kata lain WUS yang menggunakan alat KB hormonal cenderung mempunyai status yodium normal. Hasil ini mirip dengan hasil penelitian Suryati (2006) 
bahwa WUS yang menggunakan alat KB hormonal beresiko 0,18 kali untuk mengalami kadar T4 rendah ${ }^{15}$. Jadi dapat disimpulkan bahwa penggunaan alat $\mathrm{KB}$ hormonal di daerah gondok endemik tidak menyebabkan status yodium menjadi rendah.

\section{SIMPULAN DAN SARAN}

Hasil penelitian menunjukkan adanya hubungan yang bermakna antara kadar enzim kolinesterase dalam darah (CHE) dan cara memasak sayuran dengan status kadar T4 bebas(FT4). Penggunaan alat KB hormonal pada WUS didaerah penelitian tidak menyebabkan status kadar hormon tiroksin (FT4) menjadi rendah, tetapi justru sebaliknya menyebabkan status hormon tiroksin(FT4) menjadi normal.

WUS yang mempunyai kadar $\mathrm{CHE}$ rendah dalam serum beresiko 10 kali mengalami status yodium rendah dibandingkan dengan WUS dengan kadar CHE normal. Disamping itu WUS yang memasak sayuran dengan cara tumis beresiko 2,5 kali mengalami status yodium rendah dibandingkan dengan WUS yang mengkonsumsi sayuran dengan cara rebus. WUS yang menggunakan alat KB hormonal cenderung mempunyai kadar $\mathrm{T} 4$ bebas normal. Untuk mengurangi pestisida yang masuk dalam tubuh disarankan untuk mengkonsumsi sayuran dengan cara direbus.

\section{RUJUKAN}

1. Greenspan.F.S. Endokrinologi Dasar dan Klinik. E.G.C., Jakarta, 1998.

2. Directorate of Community Nutrition. Directorate General of Community Health Ministry of Health of Republic of Indonesia. Technical Assistance for Evaluation on Intensified lodine. Deficiency Control Project. Final Report. 2003.

3. Raini. M. Toksikologi Pestisida dan Penanganan Akibat Keracunan Pestisida. Media Penelitian dan
Pengembangan Kesehatan. 2007. Vol.XVII, no 3.

4. Alsuhendra, Studi Residu Pestisida pada Bahan Makanan dan Pengaruhnya terhadap Keadaan Biokimia Darah dan Organ Tubuh Tikus. Tesis Pascasarjana IPB Bogor. 1998

5. Groff.J.L and Gropper. S.S. Advanced Nutrition and Human Matabolism. Third Edition. Wadsworth. 2000.

6. Saidin S. dkk. Hubungan Status Pestisida dengan Status lodium dalam Darah pada Wanita Subur di Daerah Gondok Endemik. Departemen Kesehatan Badan Penelitian dan Pengembangan Kesehatan Pusat Penelitian dan Pengembangan Gizi dan Makanan. Laporan Penelitian. Bogor. 2005.

7. Lameshow S. et al. Adequacy of Simple Size in Health Studies. Baffins Lane. Jhon Wiley \& Sons. Chibesten, 2001..

8. WHO/UNICEF/ICCIDD. Indicator for Assessing lodine Deficiency Disorder and their Control through Salt lodization, 2001

9. Hosmer. D.W, and Stanley Lemeshow. Applied Logistic Regression. A wiley Intercine Publication. 1999.

10. Atmarita dan Lucia.V. Penggunaan indeks massa tubuh (body mass index) sebagai indikator status gizi orang dewasa. Gizi Indo. 1992,17: 50 -51.

11. Departemen Kesehatan.R.I. Pengembangan dan Penatalaksanaan Keracunan Pestisida. Subdit Pengamanan Pestisida. Jakarta. 1992.

12. Departemen Kesehatan R.I. Pusat Data Kesehatan, dalam: http://bankdata. depkes.go.id/Profil/Indo1997/Annex/liic6 $20 \mathrm{htm}$.

13. Lu. F.C. Toksikologi Dasar. Ed 2 U.I. Press, Jakarta 1998, 328 - 330

14. Novisan. Petunjuk Pemakaian Pestisida. Penerbit Agromedia, Jakarta. 2002 
Gizi Indon 2008, 31(2): 107-114 $d k k$.

15. Suryati .K. dkk. Hubungan Penggunaan Kontrasepsi Hormonal dengan Nilai
TSH dan T4 pada WUS di daerah gondok Endemik. Penelitian Gizi dan Makanan. 2004. Vol 27, no 2. 